\title{
A Composite Ranking of Risk Factors for COVID-19 Time-To-Event
}

\section{Data from a Turkish Cohort}

\author{
Ayse Ulgen ${ }^{1}$, Sirin Cetin ${ }^{2}$, Meryem Cetin ${ }^{3}$, Hakan Sivgin ${ }^{4}$, Wentian $\mathrm{Li}^{5}$ \\ 1. Department of Biostatistics, Faculty of Medicine, Girne American University, Karmi, Cyprus \\ 2. Department of Biostatistics, Tokat GaziosmanPasa University, Turkey \\ 3. Department of Medical Microbiology, Faculty of Medicine, Amasya University, Amasya, Turkey \\ 4. Department of Medical Microbiology, Tokat State Hospital, Tokat, Turkey \\ 5. The Robert S. Boas Center for Genomics and Human Genetics
}

The Feinstein Institutes for Medical Research, Northwell Health, Manhasset, NY, USA

\begin{abstract}
Having a complete and reliable list of risk factors from routine laboratory blood test for COVID-19 disease severity and mortality is important for patient care and hospital management. It is common to use metaanalysis to combine analysis results from different studies to make it more reproducible. In this paper, we propose to run multiple analyses on the same set of data to produce a more robust list of risk factors. With our time-to-event survival data, the standard survival analysis were extended in three directions. The first is to extend from tests and corresponding p-values to machine learning and their prediction performance. The second is to extend from single-variable to multiple-variable analysis. The third is to expand from analyzing time-todecease data with death as the event of interest to analyzing time-to-hospital-release data to treat early recover as a meaningful event as well. Our extension of the type of analyses leads to ten ranking lists. We conclude that 20 out of 30 factors are deemed to be reliably associated to faster-death or faster-recovery. Considering correlation among factors and evidenced by stepwise variable selection in random survival forest, $10 \sim 15$ factors seem to be able to achieve the optimal prognosis performance. Our final list of risk factors contains calcium, white blood cell and neutrophils count, urea and creatine, d-dimer, red cell distribution widths, age, ferritin, glucose, lactate dehydrogenase, lymphocyte, basophils, anemia related factors (hemoglobin, hematocrit, mean corpuscular hemoglobin concentration), sodium, potassium, eosinophils, and aspartate aminotransferase.
\end{abstract}

NOTE: This preprint reports new research that has not been certified by peer review and should not be used to guide clinical practice. 
medRxiv preprint doi: https://doi.org/10.1101/2022.01.05.22268765; this version posted January 6, 2022. The copyright holder for this preprint (which was not certified by peer review) is the author/funder, who has granted medRxiv a license to display the preprint in

It is made available under a CC-BY 4.0 International license .

\section{Introduction}

The purpose of meta analysis is to combine information from different datasets in multiple studies in order to provide robust and consistently conclusion on the effect of a factor on an outcome (Borenstein et al., 2009; Haidich, 2010). However, it is less common to attempt multiple analyses on the same set of data to extract robust information. For example, in investigating risk factors for COVID-19 infection susceptibility, disease severity (e.g. hospitalization), and mortality (Guan et al., 2020), the most common approach is to carry out one test to obtain p-value (J Tian et al., 2020; X Liu et al., 2020; Rosenthal et al., 2020; Williamson et al., 2020; Fadl et al., 2021; T Tian et al., 2020). The test can be t-test/Wilcoxon test for continuous variable, or $\chi^{2}$-test/Fisher's test for discrete variables, with the value of a risk factor in samples within two groups compared. Alternatively, uni-variable logistic regression can be used, and the null hypothesis of regression coefficient to be zero is tested. For time-to-event data (survival data), the time from hospitalization to death of a COVID-19 patient can be used to examine which factor contributes to a faster death (per unit time rate of death). This is done, for example, by the Cox regression (proportional hazard model) and the zero regression coefficient null hypothesis is tested.

In this paper, we extended the above common practice in three directions, on a COVID-19 patient time-to-event data. The first is to use both p-value based measures and prediction performance based ones. Although p-value-based approach has advantages: the meaning is easy to understand and the result is easy to report, it also has problems. P-value itself, often treated as the "gold standard for statistical validity", may not be so golden (Nuzzo, 2014). A change in true prior probability of a signal will change the prediction error even when the p-value is the same (Nuzzo, 2014; Colquhoun, 2017). There have already been proposals of alternative for p-value in evaluating variables (Lu and Ishwaran, 2018; Halsey, 2019).

The second extension is to use multiple-variable methods as well as single-variable ones. Single-variable methods evaluate a variable in isolation with respect to other variables. As a result, they would not detect conditional importance of a variable and its interaction with other variables. Inconsistency, or larger confidence interval, between different datasets concerning the importance of a factor may well reflect the contextual heterogeneity in other variables 
medRxiv preprint doi: https://doi.org/10.1101/2022.01.05.22268765; this version posted January 6, 2022. The copyright holder for this preprint (which was not certified by peer review) is the author/funder, who has granted medRxiv a license to display the preprint in

It is made available under a CC-BY 4.0 International license .

(Ghahramani et al., 2020; Kermali et al., 2020). The multi-variable statistical/machine learning models (Strobl et al., 2008) are ideal to supplement the single-variable analyses, but are less mainstream in COVID-19 data analysis (most machine learning application is on prediction and diagnosis (An et al., 2020; Li et al., 2020; McCoy et al., 2021; Li et al., 2021; Bennett et al., 2021; Karthikeyan et al., 2021; Aljameel et al., 2021; Mahdavi et al., 2021; Cornelius et al., 2021; Kocadagli et al., 2022; Malik et al., 2022)).

The third extension is specific for time-to-event data. For our inpatient data, not only have we deceased patients admission-to-death time information, but also we have larger number of patients who are completely recovered and released. In a typical survival analysis, these patients' time-to-release information would be treated as right-censored data. However, treating them as the main event of interest, extra information might be obtained (Cetin et al., 2021b,c).

With our three extensions, we are able to carry out ten analyses on the same set of data. Combining these analyses to get a composite ranking of risk factors for COVID-19 faster death or faster recover, we effectively run a meta-analysis on the same dataset. Besides the standard testing for unit hazard ratio from Cox regression (thus p-value based), we also used single-variable random survival forest (Breiman, 2001; Ishwaran et al., 2008) (thus prediction performance based), multi-variable random survival forest and variable selection in regularized regression (thus multiple variable based). Two different measures of performance (discordance index and integrated Brier score) in single-variable random survival forest are used. Then all these analyses were repeated for the time-to-release data, resulting in ten different sets of results. We will show that our composite ranking of ten runs result in a more robust list of risk factors for COVID-19 severity than the p-value based method alone, and our selected factors are fully validated by being consistent with the literature.

\section{Methods and Data}

COVID-19 patient data: Our COVID-19 patient data was collected from Amasya State Hospital (Turkey), from March 2020 to November 2020, with 3084 people and 35 potential risk factors. The 2682 outpatients do not have time-to-event data and would not be used in our survival analysis by RSF. For the remaining 402 inpatients, five factors have too much 
medRxiv preprint doi: https://doi.org/10.1101/2022.01.05.22268765; this version posted January 6, 2022. The copyright holder for this preprint (which was not certified by peer review) is the author/funder, who has granted medRxiv a license to display the preprint in

It is made available under a CC-BY 4.0 International license .

missing data (activated partial thromboplastin clotting time (aPTT), red blood cell (RBC) count, HbA1C, fibrinogen, and C-reactive protein (CRP)) and are not used. The remaining 30 factors are: age, gender, glucose, d-dimer, calcium, chloride, potassium, sodium, creatine, ferritin, urea, alanine aminotransferase (ALT), aspartate aminotransferase (AST), lactate dehydrogenase (LDH), white blood cell (WBC) or leukocyte count, neutrophils (NEU) cell count, lymphocyte (LYM) cell count, monocyte (MON) cell count, eosinophils (EOS) cell count, basophils (BAS) cell count, platelets (PLT) cell count, hemoglobin (HGB) count, hematocrit (HCT), mean corpuscular volume (MCV), mean corpuscular hemoglobin (MCH), mean corpuscular hemoglobin concentration (MCHC), red cell distribution widths (RDW.CV and RDW.SD), mean platelet volume (MPV), platelet distribution width (PDW). Some of these factors still have missing data, but none of the missing rate exceeds $14 \%$.

\section{Assessing independent variables in their contribution to time-to-event depen-}

dent variable using four methods: Our data is of the following form: 30 independent variables, $\overrightarrow{\mathbf{x}}=\left\{x_{1}, x_{2}, \cdots x_{30}\right\}$, and one dependent variable $\overrightarrow{\mathbf{y}}=\{T, \delta\}$, where $\mathrm{T}$ is the time to the event, and event status $\delta$ can take the value of 1 (event 1 , or death), 2 (event 2 , or release from hospital), 0 (right censored). We do not have any samples with right-censored time. How to handle multiple events data is usually within the scope of "competing risks" survival analysis (example: death from heart attack versus death from stroke); though in our case, the two events, risk and benefit, do not point to the same direction. How to analyze our special type of data will be discussed in the Result section. Here we simply reset $\delta=2$ to $\delta=0$ and summarize the existing methods.

All four of our analyses aim at finding which independent variable is associated with the dependent variable. We will describe each method as below. (1) In Cox regression, instead of modelling and fitting the survival function, an arbitrary baseline survival function is assumed, and a change in independent variable is assumed to lead to a constant multiple of the whole baseline curve (proportional hazard hypothesis):

$$
\frac{h\left(t, x_{i}\right)}{h_{0}(t)}=e^{\beta_{0}+\beta_{i} x_{i}} \quad(i=1,2, \cdots 30)
$$

where $h_{0}(t)$ is the arbitrary baseline hazard function, $h\left(t, x_{i}\right)$ is the hazard function with one of the independent variable present. The $\mathrm{p}$-value $p_{i}$ for testing $\beta_{i}=0$ measures the statistical 
medRxiv preprint doi: https://doi.org/10.1101/2022.01.05.22268765; this version posted January 6, 2022. The copyright holder for this preprint (which was not certified by peer review) is the author/funder, who has granted medRxiv a license to display the preprint in

It is made available under a CC-BY 4.0 International license .

significance of the contribution of $x_{i}$ to the time-to-event data, and $e^{\beta_{i}}$ measures the hazard ratio with one unit change in $x_{i}$.

(2) Random survival forest (RSF) (Ishwaran et al., 2008) is an extension of Random Forest (RF) (Breiman, 2001) to handle time-to-event data. RF/RSF construct many decision trees (therefore "forest") that separate the dependent variable value in two daughter nodes as much as possible (for introduction on RF, see, e.g., (Louppe, 2014; Fernández-Delgado, et al. 2014)). Once the splitting of nodes in a tree is done, in each external node, the cumulative hazard function (CHF) can be estimated by the Nelson-Aalen estimator (Ishwaran et al., 2008). The CHF with an independent variable $x_{i}$ can be obtained by tracing the path on the tree, according to the $x_{i}$ value, to reach the external node (Ishwaran et al., 2008):

$$
\begin{aligned}
\hat{H}_{\text {node }}(t) & =\sum_{t_{j, \text { node }}<t} \frac{d_{j, \text { node }}}{n_{\text {node }}} \\
H(t \mid \overrightarrow{\mathbf{x}}) & =\text { mean }_{\text {node, tree }} \hat{H}_{\text {node }}(t) \quad \text { (the node a bootstrap of } \overrightarrow{\mathbf{x}} \text { value leads to) }
\end{aligned}
$$

The performance of a RSF is measured by samples not used in the construction of the tree/forest, as only $1-e^{-1} \approx 63.2 \%$ of the data are used in a sample-with-replacement approach (bootstrap), and those are called out-of-bag (OOB) samples. The CHF of individual OOB samples can be obtained in a similar way by tracing the path along a tree by its independent variable values, and averaged over trees (Ishwaran et al., 2008). Averaging over all OOB samples lead to an ensemble prediction of the CHF. As all samples will become an OOB in one of run of a tree, if the number of runs is large enough, a RSF will produce a predicted CHF for each sample.

Using the predicted CHF from the RSF program, two errors can be used to measure the prediction performance. One is Harrell's concordance index (C-index) (Harrell Jr., 1982) whose complement can be called discordance index (D-index) (Cetin et al., 2021a). The C-index (Dindex) is simply the number of sample pairs whose event time and predicted CHF are consistent (not consistent), divided by the number of permissible sample pairs:

$$
\begin{aligned}
C= & \%\left(T_{j}<T_{k} \quad \& \quad H\left(t=T_{j} \mid \overrightarrow{\mathbf{x}_{\mathbf{j}}}\right)>H\left(t=T_{k} \mid \overrightarrow{\mathbf{x}_{\mathbf{k}}}\right)\right) \mathrm{j}, \mathrm{k} \text { index for permissible sample pair } \\
& D=1-C
\end{aligned}
$$

The second measure is (integrated) Brier score (IBS) (Brier, 1950), which is the squared 
medRxiv preprint doi: https://doi.org/10.1101/2022.01.05.22268765; this version posted January 6, 2022. The copyright holder for this preprint (which was not certified by peer review) is the author/funder, who has granted medRxiv a license to display the preprint in perpetuity.

It is made available under a CC-BY 4.0 International license .

difference between the actual value (e.g. binary indicator for survival) and the predicted value (e.g., predicted survival probability $\operatorname{Prob}(T>t)$ ), integrated over available time-to-event points in the sample:

$$
\begin{aligned}
B S(t) & =\frac{1}{n} \sum_{j=1}^{n} \begin{cases}\left(\operatorname{Prob}(T>t)_{j}-1\right)^{2} & \text { if } t<T_{j} \\
\operatorname{Prob}(T>t)_{j}^{2} & \text { if } t \geq T_{j}, \delta_{j}=1 \\
N A & \text { if } t \geq T_{j}, \delta_{j}=0\end{cases} \\
I B S & \approx \frac{1}{n_{T}} \sum_{j} B S\left(T_{j}\right)
\end{aligned}
$$

where $n_{T}$ is the number of samples with $\delta=1$ and the sum is over these samples.

(3) RF/RSF also provides a performance-based evaluation of individual variables when all variables $\overrightarrow{\mathbf{x}}$ are used in RF/RSF (Breiman, 2001; Ishwaran et al., 2008). We refer to the permutation based measure of variable important as VIM (the other choice is external node purity based, e.g., the Gini index (Nembrini et al., 2018)). In this approach, a variable is removed (version-1) or randomized by permuting its value among samples (version-2), and the $\mathrm{RF} / \mathrm{RSF}$ performance before and after permutation is compared:

$$
\begin{array}{ll}
\operatorname{ver} 1 & \operatorname{VIMP}\left(x_{i}\right)=\operatorname{error}\left(\overrightarrow{\mathbf{x}} \backslash x_{i}\right)-\operatorname{error}(\overrightarrow{\mathbf{x}}) \\
\operatorname{ver} 2 & \operatorname{VIMP}\left(x_{i}\right)=\operatorname{error}\left(x_{1}, x_{2}, \cdots x_{i-1}, R\left(x_{i}\right), x_{i+1}, \cdots\right)-\operatorname{error}(\overrightarrow{\mathbf{x}})
\end{array}
$$

where $R()$ refers to the random permutation step. Usually, it is the version-2 that is implemented in the commonly used programs. The variable that leads to the largest decrease of performance (or largest increase of error) is the most important variable. Note that this approach provides only a ranking of variables, and no cutoff of the list to separate important from unimportant variables is given.

(4) The regularized (Hastie et al., 2009) regression LASSO Tibshirani, (199b, 1997) for Cox regression for multiple variables is:

$$
\frac{h\left(t, x_{i}\right)}{h_{0}(t)}=\exp \left(\vec{\beta}^{T} \cdot \overrightarrow{\mathbf{x}}\right) \quad \text { conditional on } \quad \sum_{i}\left|\beta_{i}\right|<c
$$

When $c \rightarrow 0$, all regression coefficients are zero. As $c$ increases, $\left\{\beta_{i}\right\}$ gradually emerge from zero to non-zero value one by one. It is a variable selection technique, and the order of 
medRxiv preprint doi: https://doi.org/10.1101/2022.01.05.22268765; this version posted January 6, 2022. The copyright holder for this preprint (which was not certified by peer review) is the author/funder, who has granted medRxiv a license to display the preprint in

It is made available under a CC-BY 4.0 International license .

variables being selected can be used to rank them. For example, the first variable with nonzero coefficient is ranked no.1. A LASSO plot (how regression coefficient values change with the constraint) can be used to easily find the rank order.

Programs used: The R statistical platform (https://www.r-project.org) is used for our analysis. We use the $\mathrm{R}$ package randomForestSRC for random survival forest (Ishwaran and Kogalur, 2007), our own R functions for calculating IBS errors (http://github.com/wlicol/coxrsf/) (Cetin et al., 2021a), survival package for Cox regression and other survival analyses (Therneau and Grambsch, 2010). For LASSO on right-censored data, we use the R package glmnet (Simon et al., 2010). The Kendall correlation and testing of zero correlation is carried out by the R function $\operatorname{cor}$ ( . . method="kendall") and cor.test ( . . method="kendall").

In the main RSF program we used, the rfsrc function from randomForestSRC package, the default number of trees (ntree=1000), default number of variables for splitting a branch $($ mtry= $\sqrt{30} \sim 5$ ), default minimum (average) number of samples in the external nodes (nodesize $=15$ ), are used. We choose samptype = "swr" (sampling with replacement), na.action = "na.impute" (imputing the missing value). The decision to use several default parameter settings is based on our experimenting with the parameter values (Probst et al., 2019), as have been done previously (Cetin et al., 2021a). Note that sampling with replacement is not the default setting in rfsrc, but consistent with the original proposal by Breiman.

\section{Results}

Survival analyses with two types of mutually exclusive events: Our time-to-event data contains two events of very different nature. As early as 1980s, it was suggested to use a type-specific (cause-specific) use of standard survival analysis program by switching the second type event to right-censored event (i.e., convert $\delta=2$ to $\delta=0$ ) (Kalbfleisch and Prentice, 1980). The cause-specific (cs) hazard is defined as:

$$
h_{k}^{c s}(t)=\lim _{\Delta t \rightarrow 0} \frac{\operatorname{Prob}(t \leq T<t+\Delta t, K=k \mid T \geq t)}{\Delta t}, \quad k=1,2
$$

Although this definition clearly points to the possible cause-specific hazard for the second event, most people only concern about the main event, death, and do not consider the second 
medRxiv preprint doi: https://doi.org/10.1101/2022.01.05.22268765; this version posted January 6, 2022. The copyright holder for this preprint (which was not certified by peer review) is the author/funder, who has granted medRxiv a license to display the preprint in

It is made available under a CC-BY 4.0 International license .

event type.

We argue here that to run a survival analysis on the time-to-release data, while masking death as right-censored, actually provide valuable information. If $h_{2}^{c s}\left(x_{i}+1\right) / h_{2}^{c s}\left(x_{i}\right)>1$, then a higher value of $x_{i}$ leads to a faster release of a patient, and the variable- $i$ is protective. For that same variable, we would expect $h_{1}^{c s}\left(x_{i}+1\right) / h_{1}^{c s}\left(x_{i}\right)<1$ for the death event. The deceased samples should be more important in estimating $h_{1}^{c s}$. Similarly, the released samples should be more useful for the estimation of $h_{2}^{c s}\left(x_{i}\right)$. Therefore, we believe running the same survival analysis twice to find variables contributing to the two cause-specific hazard-ratios would use the dataset more fully.

In competing risk survival analysis, there is another population approach called Fine-Gray model (Fine and Gray, 1999) which defines the following subdistribution hazard:

$$
h_{k}^{s d}(t)=\lim _{\Delta t \rightarrow 0} \frac{\operatorname{Prob}(t \leq T<t+\Delta t, K=k \mid(T \geq t) \cup(T<t \cap K \neq k))}{\Delta t}, \quad k=1,2
$$

where the occurring of a type-2 event has no impact on the calculation of $h_{1}^{s d}$, with the underlying assumption that the sample experiencing type-2 event may continue to experience a type-1 event. However, this scenario is impossible in our example because our two types of events, release from hospital and die from COVID-19, are mutually exclusive. Using causespecific survival analysis for mutually exclusive events is explicitly recommended in (Allison, 2014).

Composite ranking of factors based on five measures (time-to-death): The factors are ranked five times using five measures: D-index from single-variable RSF, IBS from single-variable RSF, p-value for testing unit hazard ratio by single-variable Cox regression, permutation based VIM from the full model RSF, the variable selection order in LASSO. We found that for full-model RSF, because of random components in a run (both samples and variables are randomly chosen in a tree formation), the ranking order may change from run to run, especially for low-ranking factors. Therefore, we run the full-model RSF 100 times and the average of these runs is used.

Table 1 shows the results of these five measures. The rank for each method is within the parentheses, and the factors are listed by the overall rank order. It can be seen that some factors are consistently ranked high no matter what method is used (e.g., urea is ranked no.1 
medRxiv preprint doi: https://doi.org/10.1101/2022.01.05.22268765; this version posted January 6, 2022. The copyright holder for this preprint (which was not certified by peer review) is the author/funder, who has granted medRxiv a license to display the preprint in

It is made available under a CC-BY 4.0 International license .

by all five methods, neutrophils and calcium are ranked within top 5 by all five methods). Other factors are not ranked consistently among methods: e.g., LDH, AST are ranked high in the three RSF based methods but ranked lower by Cox and LASSO; sodium is ranked lower in single-variable RSF measures; etc. The consistency is reassuring that the very top factors would be discovered by any method. The inconsistency or variation provides a basis for our approach of combining multiple rankings to improve the robustness of the result, even for one dataset.

Composite ranking of factors based on five measures (time-to-release): Table 2 shows the similar five rankings (and the factors are ordered by the composite ranking obtained the five) with time-to-release as the dependent variable. It is interesting that different methods do not share a common top factor: the three RSF based methods pick ferritin as the top factor, whereas Cox regression picks age, and LASSO picks calcium. When the overall rank in Table 2 is combined with the overall rank in Table 1, we have a composite rank using 10 ranking lists (last column in Table 2).

To compare the time-to-death and time-to-release obtained ranking, we plot the two 1/ranks versus the composite-19 rank in Fig.1(A). Generally speaking, the two are consistent. When the two are less consistent, a "bubble" is formed. We mark the name in black if a factor is ranked higher (by more than 3) in the time-to-death analyses, and in blue if the factor is ranked higher in the time-to-release analysis (and grey if the ranks are similar). We can see that neutrophils, urea, glucose, creatine, lymphocytes, etc. are ranked higher in time-to-death runs, whereas RDW.SD, age, ferritin, HGB, etc. are ranked higher in time-to-release runs.

Fig.1(B) and (C) also show if the individual ranks within the time-to-death group and those within the time-to-release group are consistent or not. If a factor has a large variance (normalized by the mean rank) among individual ranks, it is marked by the brown color, otherwise by grey color. All curves in Fig.1 are decreasing functions, indicating a general agreement among all ranking lists.

Correlated factors: Because collinearity in a regression model is a problem of concern, we examine variable pairs that are correlated with each other. We use plotting of the raw data, correlation coefficient, p-value for testing correlation to be zero, the $R^{2}$ from regression to determination the correlation status. Several issues are considered: (1) we check the 
medRxiv preprint doi: https://doi.org/10.1101/2022.01.05.22268765; this version posted January 6, 2022. The copyright holder for this preprint (which was not certified by peer review) is the author/funder, who has granted medRxiv a license to display the preprint in

It is made available under a CC-BY 4.0 International license .

deceased samples and survived samples separately; (2) we check both the original data and log-transformed data; and for the same reason, the correlation coefficient and testing zero correlation is based on the non-parametric Spearman method; (3) if the visual impression of the scatter plot is a guide, the $R^{2}$ from regression provides a better quantity to use than, e.g. p-value for testing zero correlation.

We found six pairs of strongly correlated variables: urea and creatine, neutrophils and white blood cell, AST and ALT, RDW.CV and RDW.SD, HGB and HCT, MCV and MCH. The measure of their correlation is shown in Table 3. The lower ranked factor of a pair is marked with asterisk in Tables 1 and 2. There are more correlated variable pairs than those shown in Table 3, e.g., sodium and chloride. We use a more conservative $R^{2}$ cutoff point, and require the correlation in both survived and deceased group.

\section{Estimation of the number of independent factors that achieve the optimal pre-} diction performance: Although we have the composite ranking order of factors (both composite- 5 in Table 1 and Table 2 and composite-10 in the last column of Table 2), there is still a question of where to cut the list to select the relevant factors. Towards this, we use a stepwise variable selection, similar to that in regression (e.g. (Ryan, 2008)), but in the framework of RSF. We first need to clarify the meaning of adding or removing a variable. There are two versions: the first is actually add a variable starting from an empty field, or remove a variable starting from a full model. The second version is to keep all variables, but instead of an empty field with no variable, the null model refers to all variables being value-shuffled. Therefore, adding the first variable is to retain its values while keeping other variables scrambled. The difference between the two versions might be written as (up to step- $i$ of a variable selection):

$$
\begin{array}{ll}
\text { actual: } & (T, \delta) \sim R S F\left(x_{[1]}, x_{[2]}, \cdots x_{[i]}\right) \\
\text { vitual: } & (T, \delta) \sim R S F\left(x_{[1]}, x_{[2]}, \cdots x_{[i]}, R\left(x_{[i+1]}\right), R\left(x_{[i+2]}\right), \cdots\right)
\end{array}
$$

where the subscript $[i]$ refers to the $i$-th variable selected, and operation $\mathrm{R}$ refers to random value-shuffling.

Fig.2 shows the OOB error IBS as a function of variable selection with this variable selection 
medRxiv preprint doi: https://doi.org/10.1101/2022.01.05.22268765; this version posted January 6, 2022. The copyright holder for this preprint (which was not certified by peer review) is the author/funder, who has granted medRxiv a license to display the preprint in

It is made available under a CC-BY 4.0 International license .

criterion (to stage- $i$ ):

$$
[i]=\min _{j} I B S\left(x_{[1]}, x_{[2]}, \cdots, x_{[i-1]}, x_{j}, R\left(\overrightarrow{\mathbf{x}} \backslash\left\{x_{[1]}, x_{[2]}, \cdots, x_{[i-1]}\right\}\right)\right)
$$

where the index $j$ goes through all variables not already selected in stage- $1,2, \cdots, i-1$, and all the rest of variables not selected remain to be value-scrambled. We have run the stepwise variable selection three times each for both time-to-death RSF and time-to-release RSF. The horizontal line is the mean of IBS from 500 runs of the full model, and dashed lines are one standard deviation from the mean (for time-to-death data, IBS $=0.0945 \pm 0.000514$, and for time-to-release data IBS $=0.0753 \pm 0.000246)$.

There are several observations from these runs: (1) The full model is not the best performing model. It is related to a long debate on whether RF (or RSF here) needs variable selection or not (Díaz-Uriarte and De Andreés, 2006; Li, 2006). The Fig.2 shows that variable selection (reduction from the full model) is still needed for RF/RSF. However, we did not show the full range of IBS; and if we do, it will be seen that the problem of overfitting from the full model is less severe compared to other methods. (2) At each stage- $i$, multiple variables may have very similar IBS's and the selection of $x_{[i]}$ by Eq.(10). As a result, which particular variable is selected at stage- $i$ may change from run to run (with the exception of perhaps the first few stages). Therefore, we cannot use this procedure to select risk factors. (3) On the other hand, because the three runs (per subplot) all reach the optimal performance in the middle, we can use Fig.2 to roughly estimate the number of (independent) factors to achieve the best performance. This estimation will not be precise because different runs exhibit variations; However 10 15 (10 from Fig.2(A) and 15 from Fig.2(B)) factors should be a correct range.

Final selection of list of risk factors: Because the factor order in Fig.2 changes from run to run, we use the pre-determined rank order (column 1 in Tables 1 and 2) to check how error decrease, i.e., the $i$-th variable added in stage- $i$ is simply the rank- $(i)$ variable in the ranking list: either the composite ranking order based on 5 time-to-dead analyses or on 5 time-to-release analyses. We also use both IBS and D-index as a measure of OOB prediction errors. Furthermore, both the virtual and actual variable addition were used. The resulting error curves are shown in Fig.3 (top: time-to-death runs, bottom: time-to-release runs; left: D-index, right: IBS; black: virtual addition of variables, red: actual addition of variable). It 
medRxiv preprint doi: https://doi.org/10.1101/2022.01.05.22268765; this version posted January 6, 2022. The copyright holder for this preprint (which was not certified by peer review) is the author/funder, who has granted medRxiv a license to display the preprint in

It is made available under a CC-BY 4.0 International license .

is also possible remove the least important (low ranking) variables first (going through the ranking list backward), but the results were very similar (not shown).

It has been suggested in the literature that IBS is a better measure than D-index because it is more practical (Longato et al., 2020) and more quantitative (Kattan and Gerds, 2018). We also prefer the virtual variable addition over actual one because the change in the error curves in Fig.3 is smoother. Therefore, we use the black curve in Fig.3(B) to choose the top 14 factors, and that in Fig.3(D) to choose the top 8 factors. Using the similar error curve from the ranking order from VIM in full RSF model (columns 5 in Tables 1 and 2) (not shown), we will have a similar list of selected top factors. All these information and more are presented in Table 4.

In Table 4, we mark factors being selected by Fig.3(B), Fig.3(D), and those by two other error curves not shown. The last two columns in Table 4 mark factors which would have been selected by the standard $\mathrm{p}$-value approach $(\mathrm{p}$-value $<0.001)$. In fact, the threshold for p-value can be 0.01 , or 0.005 , and 0.001 , but we consider the threshold 0.001 to be a good choice (see, e.g., (Colquhoun, 2017; Ioannidis, 2018; Li et al., 2021)). If we choose factors that contribute to a better prediction performance, 21-22 factors would be selected, 17-18 of them are independent. These are the factors above the horizontal partition line, except potassium. We may consider chloride a borderline choice as it ranks last in our list, and monocyte as a borderline possibility. Note that the Cox regression $\mathrm{p}$-value based selection (at $\mathrm{p}=0.001$ ) would select MPV and PDW, which are not on our list.

\section{Discussions}

In this work, we have carried out a careful analysis from a single dataset to determine which factors contribute to either faster death or faster release from hospital. By a literature search, we found all our selected factors were addressed in other studies and were shown to be significantly associated with the COVID-19 disease severity. Here is a partial summary:

- Low calcium level is associated with poor prognosis of COVID-19 (Di Filippo et al., 2020; Liu et al., 2020), probably due to its role in viral infection and replication. 
medRxiv preprint doi: https://doi.org/10.1101/2022.01.05.22268765; this version posted January 6, 2022. The copyright holder for this

preprint (which was not certified by peer review) is the author/funder, who has granted medRxiv a license to display the preprint in tis made available underity.

perpetuity. 4.0 International license.

- Higher neutrophil/lymphocyte ratio (NLR) is known to be associated with severity of COVID-19 (B Zhang et al., 2020; Ma et al., 2020; Ulgen et al., 2021). Individually, higher neutrophils (Reusch et al., 2021) and lymphopenia (lower lymphocyte) (Tan et al., 2020; Tavakolpour and Rakhshandehroo, 2020) both are linked to severity. Besides blood test, proteomics based neutrophil signatures have been proposed (Meizlish et al., 2021).

- Although leukocyte count may be normal or decreased in COVID-19 patients, the incidence of leukocytosis (higher WBC) increases in ICU patients, and has been reported to be associated with COVID-19 severity (Huang et al. , 2020; Sayad et al., 2020). There is also an investigation of the causal role of WBC in disease severity by Mendelian randomization (Sun et al., 2021). Note that leukocytosis could also be related to bacterial infections, corticosteroids use, or age, and others unrelated to COVID-19 severity.

- The urea and creatine level has been observed to be higher in COVID-19 patients, and these are related to kidney abnormalities/failure, (Cheng et al., 2020; Ye et al., 2021).

- D-dimer, as a byproduct of fibrinogen degradation, is closely related to thrombosis. Ddimer has been recommended as a quantity to monitor in COVID-19 patients (Thachil et al., 2020) due to ample evidence of its association with disease severity (Tang et al., 2020; Berger et al., 2020).

- The association of red blood cell distribution width with COVID-19 severity and mortality is reported in (Foy et al. 2020; C Wang et al., 2020).

- Age is perhaps the best established risk factor for severity and mortality, see, e.g. (Williamson et al., 2020).

- Elevated ferritin serum levels have been found to significantly correlate with COVID-19 severity, as discussed in these papers (Lin et al., 2020; Carubbi et al., 2021; Ahmed et al., 2021), among others.

- The short-term glucose has been shown to be a much stronger predictor for COVID-19 severity than the history of diabetes status (Singh and Singh, 2020; Coppelli et al., 2020; Ling et al., 2021; Cetin et al., 2021d). In a recent study, it was shown that higher glucose 
medRxiv preprint doi: https://doi.org/10.1101/2022.01.05.22268765; this version posted January 6, 2022. The copyright holder for this preprint (which was not certified by peer review) is the author/funder, who has granted medRxiv a license to display the preprint in It is made available under a CC-BY 4.0 International license.

level (> 180) had increased the odds of death by 4-fold for non-diabetes, whereas only 1.8-fold increase for diabetes COVID-19 patients (Skwiersky et al, 2021).

- Lactate dehydrogenase (LDH), which was already known to be associated with poor outcome from viral infection, could predict COVID-19 severity (Henry et al., 2020; Han et al., 2020).

- Both basophils and eosinophils are found to be among the most dynamic cell populations during disease progression (Rodriguez et al., 2020), implicating them important roles played in anti-viral defense. Basophils are predicted to be a causal factor in COVID-19 severity (Sun et al., 2021), and the role of eosinophil is studied in (Lindsey et al., 2020; Xie et al., 2021; Tan et al., 2021),

- Hemoglobin and anemia has been discussed in their role of COVID-19 in (W Zhang et al., 2020; Hariyanto and Kurniawan, 2020; Benoit et al., 2021; Tao et al., 2021). Hematocrit (HCT) was mentioned as one of the laboratory tests for COVID-19 diagnosis and prognosis (Mertoglu et al., 2021). MCHC was among the lab test indicators to be significant for COVID-19 severity (Ballaz et al., 2021).

- On other essential minerals besides calcium, low abnormal sodium level (hyponatremia) was reported to be linked to COVID-19 severity (Tzoulis et al., 2021), negative association between potassium and severity was observed in (D Wang et al., 2020), while which patient population may have this correlation with hypokalemia was cautioned in (Szoke et al., 2021). It is interesting that the borderline item on our list, chloride, was not shown to be significantly associated with severity in (Lippi et al., 2020). While chloride's link was investigated in other studies, its p-values were as good as other electrolytes (Wu et al., 2020; De Carvalho et al., 2021).

- Liver biochemical biomarkers are associated with COVID-19 disease severity and clinical outcomes. Admission aspartate aminotransferase (AST) was shown to be higher in those requiring ICU stay (Gu et al. 2020; Mo et al., 2020; Ding et al., 2020; Aloisio et al., 2021). 
medRxiv preprint doi: https://doi.org/10.1101/2022.01.05.22268765; this version posted January 6, 2022. The copyright holder for this preprint (which was not certified by peer review) is the author/funder, who has granted medRxiv a license to display the preprint in

It is made available under a CC-BY 4.0 International license .

Our "within-sample-meta-analysis" lead to a more robust conclusion concerning risk factors for COVID-19 severity. Using independent studies published by other groups, our cutoff in Table 4 may lead to close to zero false discovery rate (FP/(FP+TP)) or close to $100 \%$ precision (positive predictive value, $\mathrm{TP} /(\mathrm{FP}+\mathrm{TP})$ ).

We may still underestimate the number of risk factors for the following reason. Because the number of variables selected by Figs. 2 and 3 represent the sufficient number of variables needed to achieve optimal performance, and adding more correlated/collineared variables would not decrease the error further. Among factors not selected in Table 4, several are related to platelet: PLT itself, and MPV and PDW related to platelet size. Because platelet is a key regulator of thrombosis and inflammation, both present in severe COVID-19 patients, it is a good candidate for risk factor (Barrett et al., 2021). However, it is suggested that platelet/large-cell-cell ratio (PLCR) is a better marker than MPV and PDW (Daniels et al., 2021).

In the calculation of variable VIM in RSF, one variable is removed/shuffled from the full model, and the most important variable is listed first. It is tempting to extend this for a stepwise variable selection procedure by removing/shuffling the important variable at each stage (currently we remove/shuffle the least important variable first). However, this procedure does not produce an error curve that reaches plateau (result not shown). Therefore, we did not use this procedure for deciding the cutoff in our variable list.

In conclusion, we have carried out a careful analysis on factors affecting COVID-19 hazard in a time-to-event data from a Turkish cohort. We use multiple measures and methods to rank factors, some are traditional single-variable test (Cox proportional hazard ratio model), whereas others are multiple-variable machine learning techniques (random survival forest). A novel choice in our composite ranking is to utilize shorter hospital stay for released patients to discover protective factors, which should also be a risk factor when the factor value changes in the opposite direction. This approach complements the approach in using the time-todeath information for deceased patients. All of our top choices in the composite ranking list are confirmations to one of the other studies for risk factors for COVID-19 severity and/or mortality, resulting in a $100 \%$ positive predictive value. 
medRxiv preprint doi: https://doi.org/10.1101/2022.01.05.22268765; this version posted January 6, 2022. The copyright holder for this preprint (which was not certified by peer review) is the author/funder, who has granted medRxiv a license to display the preprint in perpetuity.

It is made available under a CC-BY 4.0 International license .

Acknowledgements. WK thanks the support from the Robert S Boas Center for Genomics and Human Genetics.

\section{References}

S Ahmed, ZA Ahmed, I Siddiqui, NH Rashid, M Mansoor, L Jafri (2021), Evaluation of serum ferritin for prediction of severity and mortality in COVID-19- A cross sectional study, Ann. Med. Surg., 63:102163.

SS Aljameel, IU Khan, N Aslam, M Aljabri, ES Alsulmi (2021), Machine learning-based model to predict the disease severity and outcome in COVID-19 patients, Sci. Programming, 2021:5587188.

P Allison (2014), Event History Analysis: Regression for Longitudinal Event Data, 2nd edition (SAGE Publications).

E Aloisio, G Colombo, C Arrigo, A Dolci, M Panteghini (2021), Sources and clinical significance of aspartate aminotransferase increases in COVID-19, Clin. Chim. Acta, 522:88-95.

C An, H Lim, DW Kim, JH Chang, YJ Choi, SW Kim (2020), Machine learning prediction for mortality of patients diagnosed with COVID-19: a nationwide Korean cohort study, Sci. Rep., 10:18716.

SJ Ballaz, M Pulgar-Sánchez, K Chamorro, E Fernández-Moreira, H Ramírez, FX Mora, M Fors (2021), Common laboratory tests as indicators of COVID-19 severity on admission at high altitude: a single-center retrospective study in Quito (ECUADOR), Clin. Chem. Lab Med., 59:e326-e329.

TJ Barrett, S Bilaloglu, M Cornwell, HM Burgess, VW Virginio, K Drenkova, H Ibrahim, E Yuriditsky, Y Aphinyanaphongs, M Lifshitz, FX Liang, J Alejo, G Smith, S Pittaluga, AV Rapkiewicz, J Wang, C IancuRubin, I Mohr, K Ruggles, KA Stapleford, J Hochman, JS Berger (2021), Platelets contribute to disease severity in COVID-19, J. Throm. Haemost., https://doi.org/10.1111/jth.15534

TD Bennett, RA Moffitt, JG Hajagos, B Amor, A Anand, MM Bissell, KR Bradwell, C Bremer, JB Byrd, Alina Denham, PE DeWitt, D Gabriel, BT Garibaldi, AT Girvin, J Guinney, EL Hill, SS Hong, H Jimenez, R Kavuluru, K Kostka, HP Lehmann, E Levitt, SK Mallipattu, A Manna, JA McMurry, M Morris, J Muschelli, AJ Neumann, MMB Palchuk, ER Pfaff, Z Qian, N Qureshi, S Russell, H Spratt, A Walden, AE Williams, JT Wooldridge, YJ Yoo, XT Zhang, RL Zhu, CP Austin, JH Saltz, KR Gersing, MA Haendel, CG Chute, for the National COVID Cohort Collaborative (NC) Consortium (2021), Clinical characterization and prediction of clinical severity of SARS-CoV-2 infection among US adults using data from the US National COVID Cohort Collaborative, JAMA Netw Open, 4:e2116901.

JL Benoit, SW Benoit, MHS de Oliveira, G Lippi, BM Henry (2021), Anemia and COVID-19: A prospective perspective, J. Med. Virol., 93:708-711. 
medRxiv preprint doi: https://doi.org/10.1101/2022.01.05.22268765; this version posted January 6, 2022. The copyright holder for this preprint (which was not certified by peer review) is the author/funder, who has granted medRxiv a license to display the preprint in perpetuity.

It is made available under a CC-BY 4.0 International license .

JS Berger, D Kunichoff, S Adhikari, T Ahuja, N Amoroso, Y Aphinyanaphongs, M Cao, R Goldenberg, A Hindenburg, J Horowitz, S Parnia, C Petrilli, H Reynolds, E Simon, J Slater, S Yaghi, E Yuriditsky, J Hochman, LI Horwitz (2020), Prevalence and outcomes of d-dimer elevation in hospitalized patients with COVID-19, Arterioscler. Thromb. Vasc. Biol. 40:25392547.

M Borenstein, LV Hedges, JPT Higgins, HR Rothstein (2009), Introduction to MetaAnalysis (Wiley).

L Breiman (2001), Random forest, Machine Learning, 45:5-23.

GW Brier (1950), Verification of forecasts expressed in terms of probability, Monthly Weather Rev., 78:1-3.

F Carubbi, L Salvati, A Alunno, F Maggi, E Borghi, R Mariani, F Mai, M Paoloni, C Ferri, G Desideri, S Cicogna, Davide Grassi (2021), Ferritin is associated with the severity of lung involvement but not with worse prognosis in patients with COVID-19: data from two Italian COVID-19 units, Sci. Rep., 11:4863.

S Cetin, A Ulgen, I Dede, W Li (2021a), On fair performance comparison between Random Survival Forest and Cox regression: an example of colorectal cancer study, SciMed. J, 3(1):66-76.

S Cetin, A Ulgen, PO Balci, H Sivgin, M Cetin, S Sirgin, W Li (2021b), Survival analyses of COVID-19 patients in a Turkish cohort: comparison between using time to death and time to release, SciMed. J, 3(special issue COVID-19):1-9.

S Cetin, A Ulgen, H Sivgin, W Li (2021c), Approximate reciprocal relationship between two causespecific hazard ratios in COVID-19 data with mutually exclusive events, medRxiv preprint, doi: $10.1101 / 2021.04 .22 .21255955$

S Cetin, A Ulgen, H Sivgin, W Li (2021d), A study on factors impacting length of hospital stay of COVID-19 inpatients, J. Contemporary Medicine, 11:396-404.

Y Cheng, R Luo, K Wang, M Zhang, Z Wang, L Dong J Li, Y Yao, S Ge, G Xu (2020), Kidney disease is associated with in-hospital death of patients with COVID-19, Kidney Int., 97:829-838.

D Colquhoun (2017), The reproducibility of research and the misinterpretation of p-values, Royal Soc. Open Sci., 4:171085.

A Coppelli, R Giannarelli, M Aragona, G Penno, M Falcone, G Tiseo, L Ghiadoni, G Barbieri, F Monzani, A Virdis, F Menichetti, S Del Prato, on behalf of the Pisa COVID-19 Study Group (2020), Hyperglycemia at hospital admission is associated with severity of the prognosis in patients hospitalized for COVID-19: the Pisa COVID-19 study, Diabetes Care, 43:2345-2348.

E Cornelius, O Akman, D Hrozencik (2021), COVID-19 mortality prediction using machine learning-integrated Random Forest algorithm under varying patient frailty, Mathematics, 9:2043. 
medRxiv preprint doi: https://doi.org/10.1101/2022.01.05.22268765; this version posted January 6, 2022. The copyright holder for this preprint (which was not certified by peer review) is the author/funder, who has granted medRxiv a license to display the preprint in It is made available under a CC-BY 4.0 International license.

S Daniels, H Wei, DW Denning (2021), Platelet size as a predictor for severity and mortality in COVID-19 patients: a systematic review and meta-analysis, medRxiv preprint, doi: 10.1101/2021.07.15.21260576

H De Carvalho, MC Richard, T Chouihed, N Goffinet, Q Le Bastard, Y Freund, A Kratz, M Dubroux, D Masson, L Figueres, E Montassier (2021), Electrolyte imbalance in COVID-19 patients admitted to the Emergency Department: a casecontrol study, Intern. Emerg. Med., 16:1945-1950.

R Díaz-Uriarte and S De Andreés (2006), Gene selection and classification of microarray data using random forest, BMC Bioinf., 7:3.

ZY Ding, GX Li, L Chen, XP Chen, B Zhang (2020), Association of liver abnormalities with in-hospital mortality in patients with COVID-19, J. Hepatol., 74:1295-1302.

N Fadl, E Ali, TZ Salem (2021), COVID-19: Risk Factors Associated with Infectivity and Severity, Scand. J. Immu., 93:e13039.

M Fernández-Delgado, E Cernadas, S Barro (2014), Do we need hundreds of classifiers to solve real world classification problems? J. Machine Learning Res., 15:3133-3181.

L Di Filippo, AM Formenti, P Rovere-Querini, M Carlucci, C Conte, F Ciceri, A Zangrillo, A Giustina (2020), Hypocalcemia is highly prevalent and predicts hospitalization in patients with COVID-19, Endocrine, $68: 475478$.

JP Fine and RJ Gray (1999), A proportional hazards model for the subdistribution of a competing risk, J. Am. Stat. Asso., 94:496-509.

BH Foy, JCT Carlson, E Reinertsen, RPI Valls, RP Lopez, E Palanques-Tost, C Mow, MB Westover, AD Aguirre, JM Higgins (2020), Association of red blood cell distribution width with mortality risk in hospitalized adults with SARS-CoV-2 infection, JAMA Netw. Open, 3:e2022058.

S Ghahramani, R Tabrizi, KB Lankarani, SMA Kashani, S Rezaei, N Zeidi, M Akbari, ST Heydari, H Akbari, P Nowrouzi-Sohrabi, F Ahmadizar (2020), Laboratory features of severe vs. non-severe COVID-19 patients in Asian populations: a systematic review and meta-analysis, Euro. J. Med. Res., 25:30.

X Gu, X Li, X An, S Yang, S Wu, X Yang, H Wang (2021), Elevated serum aspartate aminotransferase level identifies patients with coronavirus disease 2019 and predicts the length of hospital stay, J. Clin. Lab Anal., 34:e23391.

WJ Guan, ZY Ni, Y Hu, WH Liang, CQ Ou, JX He, L Liu, H Shan, CL Lei, DSC Hui, B Du, LJ Li, et al. for the China Medical Treatment Expert Group for Covid-19 (2020), Clinical characteristics of coronavirus disease 2019 in China, New Eng. J. Med., 382:1708-1720. 
medRxiv preprint doi: https://doi.org/10.1101/2022.01.05.22268765; this version posted January 6, 2022. The copyright holder for this

preprint (which was not certified by peer review) is the author/funder, who has granted medRxiv a license to display the preprint in perpetuity.

It is made available under a CC-BY 4.0 International license.

AB Haidich (2010), Meta-analysis in medical research, Hippokratia, 14(suppl 1):29-37.

LG Halsey (2019), The reign of the p-value is over: what alternative analyses could we employ to fill the power vacuum? Biol. Lett., 15:20190174.

Y Han, H Zhang, S Mu, W Wei, C Jin, C Tong, Z Song, Y Zha, Y Xue, G Gu (2020), Lactate dehydrogenase, an independent risk factor of severe COVID-19 patients: a retrospective and observational study, Aging, 12:11245-11258.

TI Hariyanto and A Kurniawan (2020), Anemia is associated with severe coronavirus disease 2019 (COVID-19) infection, Transf. Apheresis Sci., 59:102926.

FE Harrell Jr., RM Califf, DB Pryor, KL Lee, RA Rosati (1982), Evaluating the yield of medical tests, JAMA, $247: 2543-2546$.

T Hastie, R Tibshirani, J Friedman (2009), The Elements of Statistical Learning, 2nd editor (Springer).

BM Henry, G Aggarwal, J Wong, S Benoit, J Vikse, M Plebani, G Lippi (2020), Lactate dehydrogenase levels predict coronavirus disease 2019 (COVID-19) severity and mortality: a pooled analysis, Am. J. Emerg. Med., 38:1722-1726.

G Huang, AJ Kovalic, CJ Graber (2020), Prognostic value of leukocytosis and lymphopenia for coronavirus disease severity, Emerg. Infect. Dis., 26:1839-1841.

JPA Ioannidis (2018), The proposal to lower P value thresholds to .005, JAMA, 319:1429-1430.

H Ishwaran and UB Kogalur (2007), Random survival forests for R, Rnews, 7:25-31.

H Ishwaran, UB Kogalur, EH Blackstone, MS Lauer (2008), Random survival forest, Ann. Appl. Stat., 2:841860.

JD Kalbfleisch and RL Prentice (1980), The Statistical Analysis of Failure Time Data (Wiley-Interscience).

A Karthikeyan, A Garg, PK Vinod, UD Priyakumar (2021), Machine learning based clinical decision support system for early COVID-19 mortality prediction, Front. Public Health, 9:475.

MW Kattan and TA Gerds (2018), The index of prediction accuracy: an intuitive measure useful for evaluating risk prediction models, Diagn. Progn. Res., 2:7.

M Kermali, RK Khalsa, K Pillai, Z Ismail, A Harky (2020), The role of biomarkers in diagnosis of COVID-19 - A systematic review, Life Sci., 254:117788.

O Kocadagli, A Baygul, N Gokmen, S Incir, C Aktan (2022), Clinical prognosis evaluation of COVID-19 patients: An interpretable hybrid machine learning approach, Curr. Res. Transl. Med., 70:103319. 
medRxiv preprint doi: https://doi.org/10.1101/2022.01.05.22268765; this version posted January 6, 2022. The copyright holder for this preprint (which was not certified by peer review) is the author/funder, who has granted medRxiv a license to display the preprint in perpetuity.

It is made available under a CC-BY 4.0 International license .

MB Kursa (2014), Robustness of Random Forest-based gene selection methods, BMC Bioinformatics, 15:8.

M Li, Z Zhang, W Cao, Y Liu, B Du, C Chen, Q Liu, MN Uddin, S Jiang, C Chen, Y Zhang, X Wang (2021), Identifying novel factors associated with COVID-19 transmission and fatality using the machine learning approach, Sci. Total Environ, 764:142810.

W Li (2006), The-more-the-better and the-less-the-better, Bioinformatics, 22:2187-2188.

W Li, A Shih, Y Freudenberg-Hua, W Fury, Y Yang (2021), Beyond standard pipeline and $p<0.05$ in pathway enrichment analyses, Comp. Biol. and Chem., 92:107455.

WT Li, J Ma, N Shende, G Castaneda, J Chakladar, JC Tsai, L Apostol, CO Honda, J Xu, LM Wong, T Zhang, A Lee, A Gnanasekar, TK Honda, SZ Kuo, MA Yu, EY Chang, M Rajasekaran, WM Ongkeko (2020), Using machine learning of clinical data to diagnose COVID-19: a systematic review and meta-analysis, BMC Med. Inf. Dec. Making, 20:247.

Z Lin, F Long, Y Yang, X Chen, L Xu, M Yang (2020), Serum ferritin as an independent risk factor for severity in COVID-19 patients, J. Infect., 81:647-679.

AW Lindsley, JT Schwartz, ME Rothenberg (2020), Eosinophil responses during COVID-19 infections and coronavirus vaccination, J. Allergy and Clin. Immun., 146:1-7.

P Ling, S Luo, X Zheng, G Cai, J Weng (2020), Elevated fasting blood glucose within the first week of hospitalization was associated with progression to severe illness of COVID-19 in patients with preexisting diabetes: A multicenter observational study, J. Diabetes, 13:89-93.

G Lippi, A M South, BM Henry (2020), Electrolyte imbalances in patients with severe coronavirus disease 2019 (COVID-19), Ann. Clin. Biochem., 57:262-265.

J Liu, P Han, J Wu, J Gong, D Tian (2020), Prevalence and predictive value of hypocalcemia in severe COVID-19 patients, J. Infect. Pub. Health, 13:1224-1228.

X Liu, H Zhou, Y Zhou, X Wu, Y Zhao, Y Lu, W Tan, M Yuan, X Ding, J Zou, R Li, H Liu, RM Ewing, Y Hu, H Nie, Y Wang (2020), Risk factors associated with disease severity and length of hospital stay in COVID-19 patients, J. Infect., 81:e95-e97.

E Longato, M Vettoretti, B Di Camillo (2020), A practical perspective on the concordance index for the evaluation and selection of prognostic time-to-event models, J. Biomed. Inform., 108:103496.

G Louppe (2014), Understanding random forests: from theory to practice, Ph.D Thesis (Department of Electrical Engineering and Computer Science, Universite de Liége). 
medRxiv preprint doi: https://doi.org/10.1101/2022.01.05.22268765; this version posted January 6, 2022. The copyright holder for this preprint (which was not certified by peer review) is the author/funder, who has granted medRxiv a license to display the preprint in perpetuity.

It is made available under a CC-BY 4.0 International license .

M Lu and H Ishwaran (2018), J. Thorac. Card. Surg., 155:1130-1136.

A Ma, J Cheng, J Yang, M Dong, X Liao, Y Kang (2020), Neutrophil-to-lymphocyte ratio as a predictive biomarker for moderate-severe ARDS in severe COVID-19 patients, Critical Care, 24:288.

M Mahdavi, H Choubdar, E Zabeh, M Rieder, S Safavi-Naeini, Z Jobbagy, A Ghorbani, A Abedini, A Kiani, V Khanlarzadeh, R Lashgari, E Kamrani (2021), A machine learning based exploration of COVID-19 mortality risk, PLoS ONE, 16:e0252384.

M Malik, MW Iqbal, SK Shahzad, MT Mushtaq, MR Naqvi, M Kamran, BA Khan, MU Tahir (2022), Determination of COVID-19 patients using machine learning algorithms, Intell. Automation Soft Comput., $31: 207-222$.

D McCoy, W Mgbara, N Horvitz, WM Getz, A Hubbard (2021), Ensemble machine learning of factors influencing COVID-19 across US counties, Sci. Rep., 11:11777.

ML Meizlish, AB Pine, JD Bishai, G Goshua, ER Nadelmann, M Simonov, CH Chang, H Zhang, M Shallow, P Bahel, K Owusu, Y Yamamoto, T Arora, DS Atri, A Patel, R Gbyli, J Kwan, CH Won, C Dela Cruz, C Price, J Koff, BA King, HM Rinder, FP Wilson, J Hwa, S Halene, W Damsky, D van Dijk, AI Lee, HJ Chun (2021), A neutrophil activation signature predicts critical illness and mortality in COVID-19, Blood Adv., 5:1164-1177.

C Mertoglu, MT Huyut, Y Arslan, Y Ceylan, TA Coban (2021), How do routine laboratory tests change in coronavirus disease 2019? Scand. J. Clin. Lab. Invest., 81:24-33.

P Mo, Y Xing, Y Xiao, L Deng, Q Zhao, H Wang, Y Xiong, Z Cheng, S Gao, K Liang, M Luo, T Chen, S Song, Z Ma, X Chen, R Zheng, Q Cao, F Wang, Y Zhang (2020), Clinical characteristics of refractory COVID-19 pneumonia in Wuhan, China, Clin. Infect. Dis., 2020:ciaa270.

S Nembrini, IR König, MN Wright (2018), The revival of the Gini importance? Bioinf., 34:3711-3718.

R Nuzzo (2014), Scientific method: statistical errors: p values, the gold standard of statistical validity, are not as reliable as many scientists assume, Nature, 506:150-152.

P Probst, MN Wright, AL Boulesteix (2019), Hyperparameters and tuning strategies for random forest, WIREs Data Mining and Knowledge Discovery, 9:e1301.

N Reusch, E De Domenico, L Bonaguro, J Schulte-Schrepping, K Bassler, JL Schultze, AC Aschenbrenner (2021), Neutrophils in COVID-19, Front. Immunol., 12:652470.

L Rodriguez, PT Pekkarinen, T Lakshmikanth, Z Tan, CR Consiglio, C Pou, Y Chen, CH Mugabo, NA Nguyen, K Nowlan, T Strandin, L Levanov, J Mikes, J Wang, A Kantele, J Hepojoki, O Vapalahti, S 
medRxiv preprint doi: https://doi.org/10.1101/2022.01.05.22268765; this version posted January 6, 2022. The copyright holder for this

preprint (which was not certified by peer review) is the author/funder, who has granted medRxiv a license to display the preprint in perpetuity.

It is made available under a CC-BY 4.0 International license .

Heinonen, E Kekäläinen, P Brodin 2020), Systems-level immunomonitoring from acute to recovery phase of severe COVID-19, Cell Rep. Med., 1:100078.

N Rosenthal, Z Cao, J Gundrum, J Sianis, S Safo (2020), Risk factors associated with in-hospital mortality in a US national sample of patients with COVID-19, JAMA Newtwork Open, 3:e2029058.

TP Ryan (2008), Modern Regression Methods, 2nd edition (Wiley).

B Sayad, ZM Afshar, F Mansouri, Z Rahimi (2020), Leukocytosis and alteration of hemoglobin level in patients with severe COVID-19: association of leukocytosis with mortality, Health Sci. Rep., 3:e194.

AK Singh and R Singh (2020), Hyperglycemia without diabetes and new-onset diabetes are both associated with poorer outcomes in COVID-19, Diabetes Res. and Clin. Prac., 167:108382.

N Simon, J Friedman, T Hastie, R Tibshirani (2011), Regularization paths for Coxs proportional hazards model via coordinate descent, J. Stat. Software, 39:113.

S Skwiersky, S Rosengarten, M Change, et al. (2021), Sugar is not always sweet: exploring the relationship between hyperglycemia and COVID-19 in a predominantly African American population. J. Endo. Soc., $5($ suppl 1):A350.

C Strobl, AL Boulesteix, T Kneib, T Augustin, A Zeileis (2008), Conditional variable importance for random forests, BMC Bioinf., 9:307.

Y Sun, J Zhou, K Ye (2021), White blood cells and severe COVID-19: a Mendelian randomization study, J. Pers. Med., 11:195.

D Szoke, S Caruso, E Aloisio, S Pasqualetti, A Dolci, M Panteghini (2021), Serum potassium concentrations in COVID-19, Clinica Chimica Acta, 512:26-27.

L Tan, Q Wang, D Zhang, J Ding, Q Huang, YQ Tang, Q Wang, H Miao (2020), Lymphopenia predicts disease severity of COVID-19: a descriptive and predictive study, SIgnal Transd. Target. Therapy, 5:33.

Y Tan, J Zhou, Q Zhou, L Hu, Y Long, (2021), Role of eosinophils in the diagnosis and prognostic evaluation of COVID-19, J. Med. Virol., 93:1105-1110.

N Tang, D Li, X Wang, Z Sun (2020), Abnormal coagulation parameters are associated with poor prognosis in patients with novel coronavirus pneumonia, J. Thrombosis and Haemost., 18:844-847.

Z Tao, J Xu, W Chen, Z Yang, X Xu, L Liu, R Chen, J Xie, M Liu, J Wu, H Wang, J Liu (2021), Anemia is associated with severe illness in COVID-19: A retrospective cohort study, J. Med. Virol., 93:1478-1488. 
medRxiv preprint doi: https://doi.org/10.1101/2022.01.05.22268765; this version posted January 6, 2022. The copyright holder for this preprint (which was not certified by peer review) is the author/funder, who has granted medRxiv a license to display the preprint in perpetuity.

It is made available under a CC-BY 4.0 International license .

S Tavakolpour and T Rakhshandehroo (2020), Lymphopenia during the COVID-19 infection: What it shows and what can be learned, Immunol. Lett., 225:31-32.

J Thachil, N Tang, S Gando, A Falanga, M Cattaneo, M Levi, C Clark, T Iba (2020), ISTH interim guidance on recognition and management of coagulopathy in COVID19, J. Thromb. Haemost. , 18:1023-1026.

TM Therneau and PM Grambsch (2010). Modeling Survival Data: Extending the Cox Model (Springer).

J Tian, X Yuan, J Xiao, Q Zhong, C Yang, B Liu, Y Cai, Z Lu, J Wang, Y Wang, S Liu, B Cheng, J Wang, M Zhang, L Wang, S Niu, Z Yao, X Deng, F Zhou, W Wei, Q Li, X Chen, W Chen, Q Yang, S Wu, J Fan, B Shu, Z Hu, S Wang, XP Yang, W Liu, X Miao, Z Wang (2020), Clinical characteristics and risk factors associated with COVID-19 disease severity in patients with cancer in Wuhan, China: a multicentre, retrospective, cohort study, Lancet, 21:893-903.

T Tian, J Zhang, L Hu, Y Jiang, C Duan, Z Li, X Wang, H Zhang (2021), Risk factors associated with mortality of COVID-19 in 3125 counties of the United States, Infect. Dis. Poverty, 10:3.

R Tibshirani (1996), Regression Shrinkage and Selection via the lasso, J. Royal Stat. Soc. B, 58:26788.

R Tibshirani (1997), The lasso method for variable selection in the Cox model, Stat. Med. , 16:385395.

P Tzoulis, JA Waung, E Bagkeris, Z Hussein, A Biddanda, J Cousins, A Dewsnip, K Falayi, W McCaughran, C Mullins, A Naeem, M Nwokolo, H Quah, S Bitat, E Deyab, S Ponnampalam, PM Bouloux, H Montgomery, SE Baldeweg (2021), Dysnatremia is a predictor for morbidity and mortality in hospitalized patients with COVID-19, J. Clin. Edo. Meta., 106:1637-1648.

A Ulgen, S Cetin, PO Balci, H Sivgin, S Sivgin, M Cetin, W Li (2021) COVID-19 outpatients and surviving inpatients exhibit comparable blood test results that are distinct from non-surviving inpatients, Health Sciences Medicine, 4(3):306-313.

C Wang, H Zhang, X Cao, R Deng, Y Ye, Z Fu, L Gou, F Shao, J Li, W Fu, X Zhang, X Ding, J Xiao, C Wu, T Li, H Qi, C Li, Z Lu (2020), Red cell distribution width (RDW): a prognostic indicator of severe COVID-19, Ann. Transl. Med., 8:120.

D Wang, R Li, J Wang, Q Jiang, C Gao, J Yang, L Ge, Q Hu (2020), Correlation analysis between disease severity and clinical and biochemical characteristics of 143 cases of COVID-19 in Wuhan, China: a descriptive study, BMC Infec. Dis., 20:519.

EJ Williamson, AJ Walker, K Bhaskaran, S Bacon, C Bates, CE Morton, HJ Curtis, A Mehrkar, D Evans, P Inglesby, J Cockburn, HI McDonald, B MacKenna, L Tomlinson, IJ Douglas, CT Rentsch, R Mathur, AYS Wong, R Grieve, D Harrison, H Forbes, A Schultze, R Croker, J Parry, F Hester, S Harper, R Perera, SJW 
medRxiv preprint doi: https://doi.org/10.1101/2022.01.05.22268765; this version posted January 6, 2022. The copyright holder for this

preprint (which was not certified by peer review) is the author/funder, who has granted medRxiv a license to display the preprint in perpetuity.

It is made available under a CC-BY 4.0 International license .

Evans, L Smeeth, B Goldacre (2020), Factors associated with COVID-19-related death using OpenSAFELY, Nature, 584:430-436.

Y Wu, B Hou, J Liu, Y Chen, P Zhong (2020), Risk factors associated with long-term hospitalization in patients with COVID-19: a single-centered, retrospective study, Front. Med., 7:315.

G Xie, F Ding, L Han, D Yin, H Lu, M Zhang (2021), The role of peripheral blood eosinophil counts in COVID-19 patients, Allergy, 76:471-482.

B Ye, H Deng, H Zhao, J Liang, L Ke, W Li (2021), Association between an increase in blood urea nitrogen at 24h and worse outcomes in COVID-19 pneumonia, Renal Failure, 43:347-350.

B Zhang, X Zhou, C Zhu, Y Song, F Feng, Y Qiu, J Feng, Q Jia, Q Song, B Zhu, J Wang (2020), Immune phenotyping based on the neutrophil-to-lymphocyte ratio and IgG level predicts disease severity and outcome for patients with COVID-19, Frontiers in Mol. Biosci.,7:157.

W Zhang, Z Zhang, Y Ye, Y Luo, S Pan, H Qi, Z Yu, J Qu (2020), Lymphocyte percentage and hemoglobin as a joint parameter for the prediction of severe and nonsevere COVID-19: a preliminary study, Ann. Transl. Med., 8:1231. 
medRxiv preprint doi: https://doi.org/10.1101/2022.01.05.22268765; this version posted January 6, 2022. The copyright holder for this preprint (which was not certified by peer review) is the author/funder, who has granted medRxiv a license to display the preprint in It is made available under a CC-BY 4.0 International license.
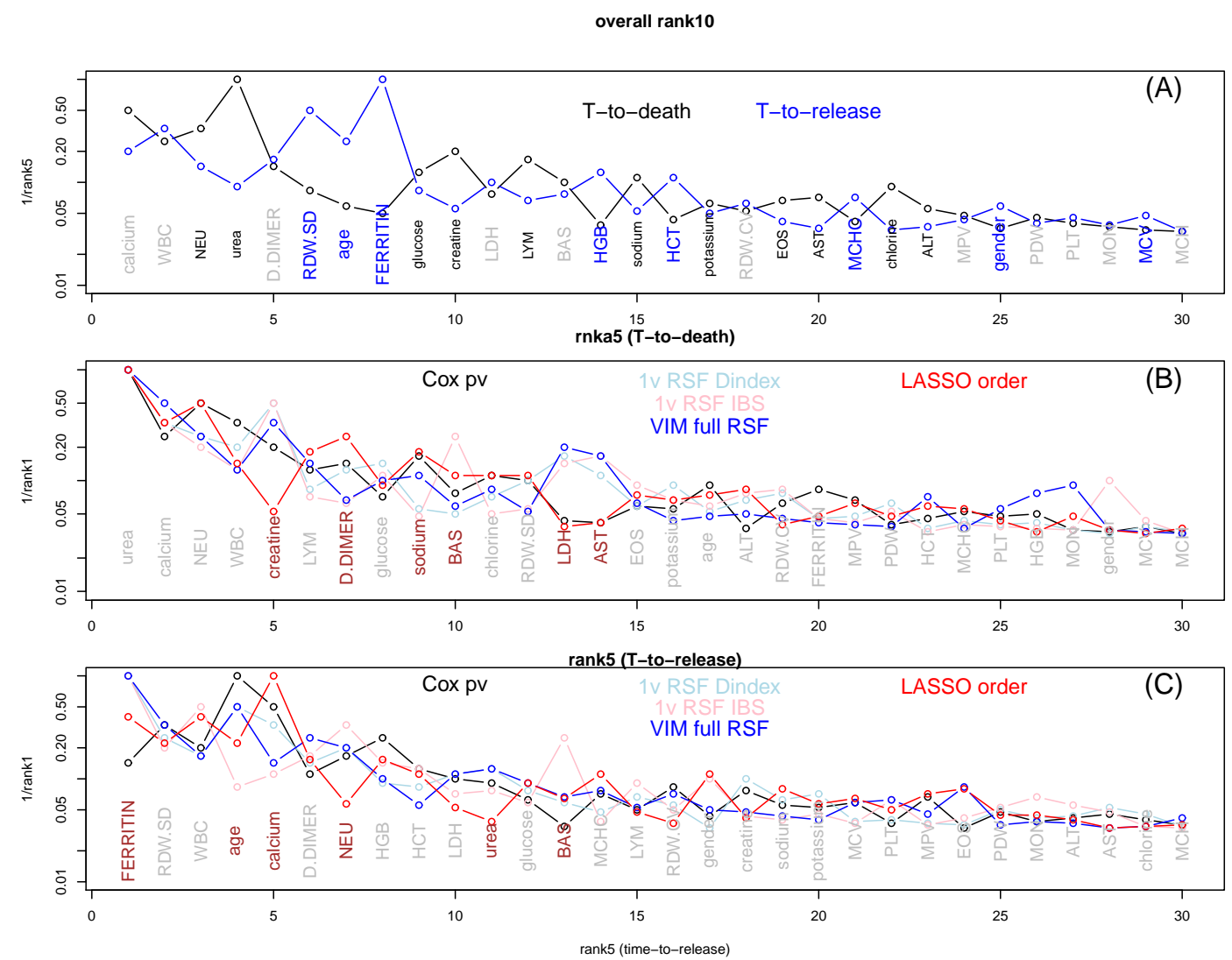

Figure 1: (A) Comparing the composite rank based on 5 time-to-death analyses (black) and the composite rank based on 5 time-to-release analysis (blue). The x-axis is the composite rank based on 10 analyses, and $\mathrm{y}$-axis is $1 /$ (composite rank using 5 analyses). (B) Comparing the five ranks obtained from five time-to-death analysis. The $\mathrm{x}$-axis is the composite rank and y-axis is 1/(individual rank). (C) Similar to (B) for ranks from five time-to-release analyses. 
medRxiv preprint doi: https://doi.org/10.1101/2022.01.05.22268765; this version posted January 6, 2022. The copyright holder for this preprint (which was not certified by peer review) is the author/funder, who has granted medRxiv a license to display the preprint in perpetuity.

It is made available under a CC-BY 4.0 International license .

(A) T-to-death

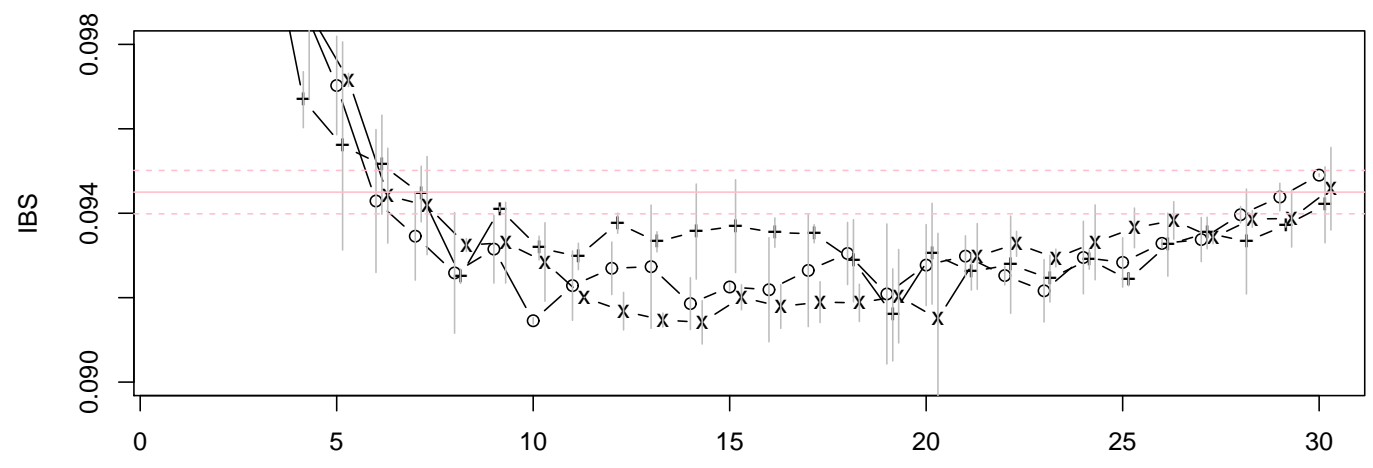

(B) T-to-release

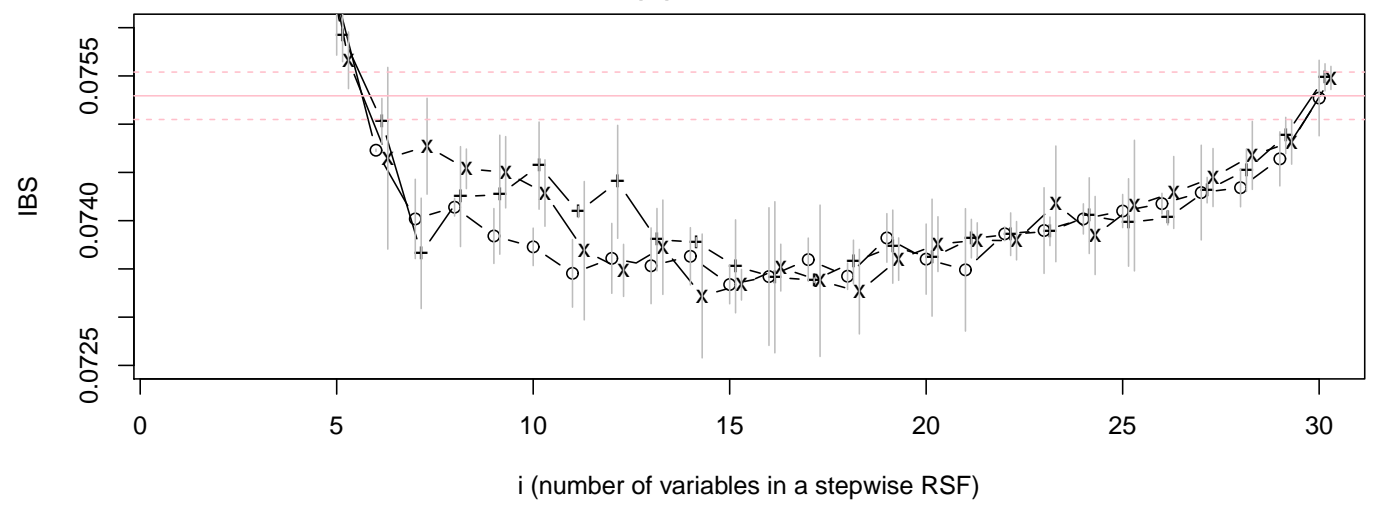

Figure 2: IBS from OOB samples in RSF run with the stepwise variable selection (Eq.(10)), for time-to-death data (A) and time-to-release data (B). For each variable at each stage, 10 RSF runs were carried out. The variable with the lowest mean IBS is selected, and its mean the one standard deviation up or down are shown in a vertical bar. The whole process is repeated three times (for (A) and for (B) separately). The larger IBS's with few variables $(i<5)$ are cut off in order to zoom in the middle range of $i$ 's. 
medRxiv preprint doi: https://doi.org/10.1101/2022.01.05.22268765; this version posted January 6, 2022. The copyright holder for this preprint (which was not certified by peer review) is the author/funder, who has granted medRxiv a license to display the preprint in It is made available under a CC-BY 4.0 International license.

(A) T-to-death/Dindex

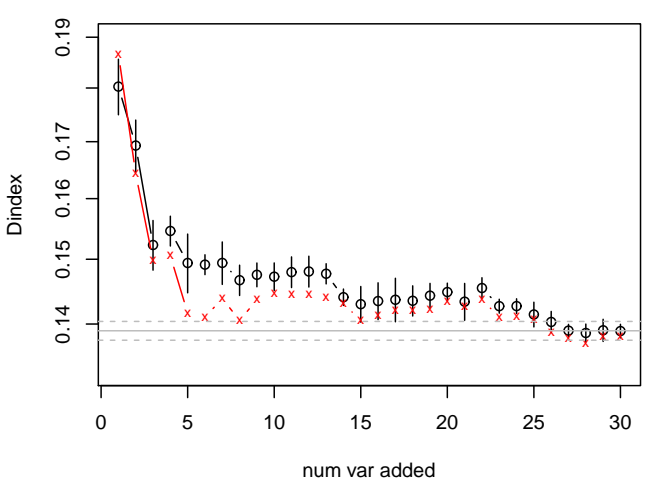

(C) T-to-release/Dindex

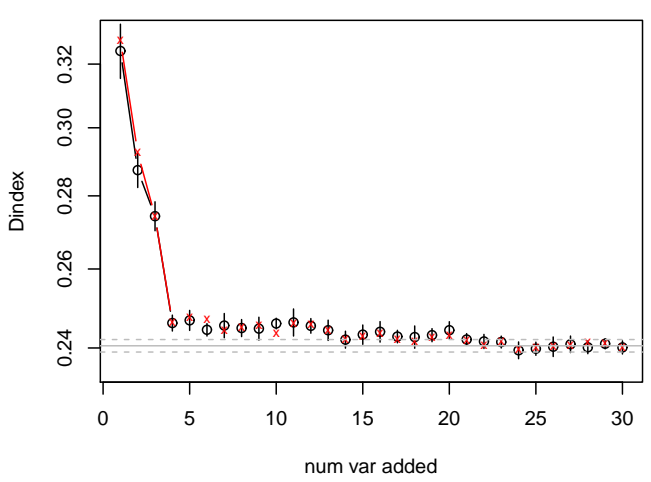

(B) T-to-death/IBS

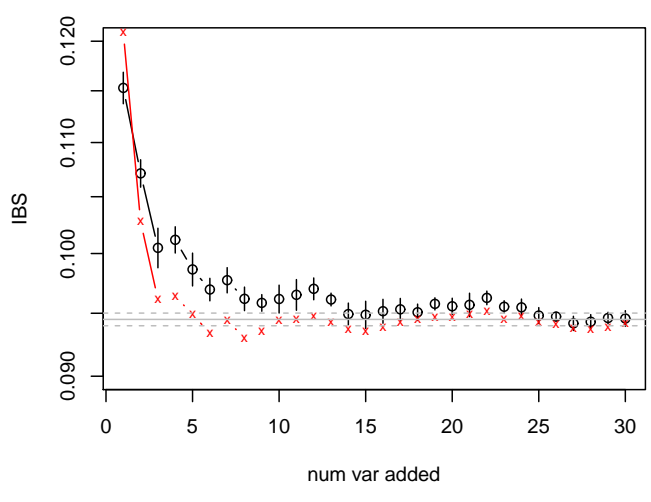

(D) T-to-release/IBS

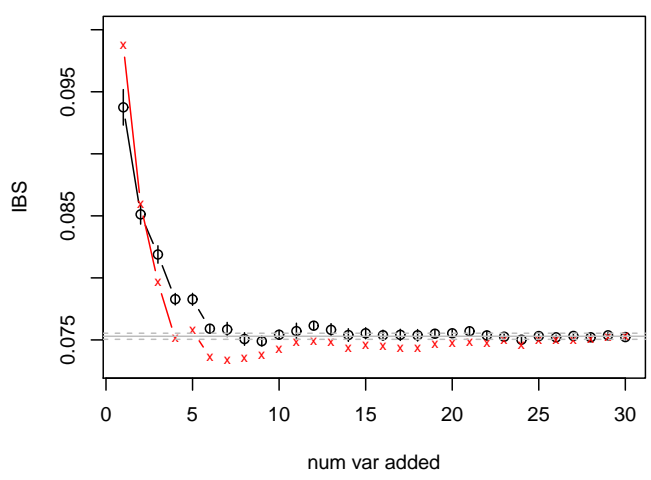

Figure 3: OOB RSF error (D-index on left, IBS on right) for time-to-dead (top) and time-to-release (bottom) data, as a function of $i$ (stage- $i$ of addition of the top- $i$ ranked factors), with black for virtual variable addition and red for actual addition. The horizontal line is the mean and one standard deviation away from the mean of the full model errors (from 500 runs). The vertical bar represents one standard deviation away from the mean at stage- $i$ by 10 runs. 


\begin{tabular}{|c|c|c|c|c|c|}
\hline $\begin{array}{l}\text { combined rank } \\
\text { (time-to-death) }\end{array}$ & var & $\begin{array}{c}\text { single-var RSF } \\
\text { D(rank), IBS(rank) }\end{array}$ & $\begin{array}{c}\text { Cox } \\
\text { pv(rank })\end{array}$ & $\begin{array}{c}\mathrm{C} \text { full RSF } \\
\mathrm{VIM} \times 10^{3} \text { (rank) }\end{array}$ & $\begin{array}{r}\text { LASSO } \\
\text { (rank) }\end{array}$ \\
\hline 1 & urea & $.186(1), .121(1)$ & $1.4 \mathrm{E}-19(1)$ & $38.2(1)$ & (1) \\
\hline 2 & calcium & $.220(3), .131(3)$ & $5.6 \mathrm{E}-14(4)$ & $12.6(2)$ & (3) \\
\hline 3 & NEU & $.235(4), .141(5)$ & $3.1 \mathrm{E}-16(2)$ & $9.05(4)$ & (2) \\
\hline 4 & $W B C^{*}$ & $.252(5), .153(8)$ & $2.2 \mathrm{E}-14(3)$ & $5.05(8)$ & (7) \\
\hline 5 & creatine $^{*}$ & $.214(2), .127(2)$ & $2.1 \mathrm{E}-12(5)$ & $10.6(3)$ & (19) \\
\hline 6 & LYM & $.326(12), .167(14)$ & $1.3 \mathrm{E}-9(8)$ & $5.3(7)$ & $(5.5 \mathrm{~T})$ \\
\hline 7 & d-dimer & $.3(8), .167(16)$ & $1.1 \mathrm{E}-9(7)$ & $1.13(15)$ & $(4)$ \\
\hline 8 & glucose & $.281(7), .154(9)$ & $4.4 \mathrm{E}-5(14)$ & $2.69(10)$ & (11) \\
\hline 9 & sodium & $.367(18), .18(21)$ & $4.2 \mathrm{E}-11(6)$ & $2.6(9)$ & $(5.5 \mathrm{~T})$ \\
\hline 10 & BAS & $.377(20), .14(4)$ & $2.4 \mathrm{E}-6(13)$ & $0.98(17)$ & $(9 \mathrm{~T})$ \\
\hline 11 & chloride & $.35(14), .175(20)$ & $4.24 \mathrm{E}-8(9)$ & $1.32(12)$ & $(9 \mathrm{~T})$ \\
\hline 12 & RDW.SD & $.313(10), .171(18)$ & $5.8 \mathrm{E}-8(10)$ & $.56(19)$ & $(9 \mathrm{~T})$ \\
\hline 13 & LDH & $.26(6), .15(7)$ & $.015(23)$ & $7.56(5)$ & (26) \\
\hline 14 & $\mathrm{AST}$ & $.302(9), .15(6)$ & $.021(24)$ & $5.54(6)$ & (24) \\
\hline 15 & EOS & $.365(17), .164(11)$ & $4 \mathrm{E}-4(17)$ & $1(16)$ & $(13.5 \mathrm{~T})$ \\
\hline 16 & potassium & $.319(11), .167(15)$ & $5.7 \mathrm{E}-4(18)$ & $0.279(23)$ & $(15)$ \\
\hline 17 & age & $.373(19), .171(17)$ & 8.7E-8 (11) & $0.319(21)$ & $(13.5 \mathrm{~T})$ \\
\hline 18 & $A L T *$ & $.354(15), .165(13)$ & $.0403(27)$ & $0.454(20)$ & (12) \\
\hline 19 & $R D W . C V^{*}$ & $.335(13), .165(12)$ & $1.7 \mathrm{E}-4(16)$ & $0.29(22)$ & (25) \\
\hline 20 & ferritin & $.38(22), .183(22)$ & $3.6 \mathrm{E}-7(12)$ & $0.186(24)$ & (21) \\
\hline 21 & $\mathrm{MPV}$ & $.378(21), .192(24)$ & $1.5 \mathrm{E}-4(15)$ & $0.0648(25)$ & (16) \\
\hline 22 & PDW & $.356(16), .174(19)$ & $.036(25)$ & $-0.0178(26)$ & (21) \\
\hline 23 & $H C T$ & $.474(27), .214(29)$ & $.008(22)$ & $1.16(14)$ & (17) \\
\hline 24 & $\mathrm{MCHC}$ & $.407(23), .193(25)$ & $.0011(19)$ & $-0.047(27)$ & (18) \\
\hline 25 & PLT & $.443(25), .2(26)$ & $.0019(21)$ & $0.88(18)$ & (23) \\
\hline 26 & HGB * & $.416(24), .206(27)$ & $.0014(20)$ & $1.22(13)$ & (29) \\
\hline 27 & $M O N$ & $.475(28), .208(28)$ & $.49(28)$ & $1.35(11)$ & (21) \\
\hline 28 & gender & $.637(30), .155(10)$ & $.83(29)$ & $-0.06(28)$ & (28) \\
\hline 29 & $M C V$ & $.461(26), .189(23)$ & $.037(26)$ & $-0.1(29)$ & $(30)$ \\
\hline 30 & $M C H$ * & $.561(29), .218(30)$ & $.86(30)$ & $-0.21(30)$ & (27) \\
\hline
\end{tabular}

Table 1: Composite ranking of factors based on time-to-death of COVID-19. Column 1 (Col-1): composite rank from five analyses; Col-2: names of factor; Col-3: two error measures of single-variable random survival forest (RSF): discordance index (D) and integrated Brier score (IBS). The number in the parenthesis is the rank (also for Cols 4-6); Col-4: p-value from single-variable Cox regression; Col-5: permutation-based variable importance (VIM) from the full RSF model, averaged over 100 runs; COl-6: (ranking according to the variable selection order from LASSO; T for tied rank). 
medRxiv preprint doi: https://doi.org/10.1101/2022.01.05.22268765; this version posted January 6, 2022. The copyright holder for this

preprint (which was not certified by peer review) is the author/funder, who has granted medRxiv a license to display the preprint in perpetuity

It is made available under a CC-BY 4.0 International license.

\begin{tabular}{|c|c|c|c|c|c|c|}
\hline $\begin{array}{l}\text { combined rank } \\
\text { (time-to-release) }\end{array}$ & var & $\begin{array}{c}\text { single-var RSF } \\
\text { D(rank), IBS(rank) }\end{array}$ & $\begin{array}{c}\text { Cox } \\
\text { pv(rank })\end{array}$ & $\begin{array}{c}\mathrm{C} \text { full RSF } \\
\mathrm{VIM} \times 10^{3}(\mathrm{rank})\end{array}$ & $\begin{array}{l}\text { LASSO } \\
(\text { rank })\end{array}$ & $\begin{array}{c}\text { composite10 } \\
\text { (rank) }\end{array}$ \\
\hline 1 & ferritin & $.327(1), .099(1)$ & $1.9 \mathrm{E}-17(7)$ & $21.4(1)$ & $(2.5 \mathrm{~T})$ & (8) \\
\hline 2 & RDW.SD & $.355(4), .103(5)$ & $2.6 \mathrm{E}-19(3)$ & $7.87(3)$ & $(4.5 \mathrm{~T})$ & (6) \\
\hline 3 & $W B C$ & $.361(6), .1(2)$ & $8.8 \mathrm{E}-18(5)$ & $5.8(6)$ & $(2.5 \mathrm{~T})$ & (2) \\
\hline 4 & age & $.338(2), .108(12)$ & $1.5 \mathrm{E}-27(1)$ & $15.8(2)$ & $(4.5 \mathrm{~T})$ & (7) \\
\hline 5 & calcium & $.354(3), .107(9)$ & $3.8 \mathrm{E}-21(2)$ & $4.08(7)$ & (1) & (1) \\
\hline 6 & d-dimer & $.368(7), .104(6)$ & $3.6 \mathrm{E}-15(9)$ & $6.56(4)$ & $(6.5 \mathrm{~T})$ & (5) \\
\hline 7 & $\mathrm{NEU} *$ & $.359(5), .102(3)$ & $1.1 \mathrm{E}-17(6)$ & $6.48(5)$ & $(17.5 \mathrm{~T})$ & $(3)$ \\
\hline 8 & HGB & $.39(11), .105(7)$ & $6.4 \mathrm{E}-19(4)$ & $1.89(10)$ & $(6.5 \mathrm{~T})$ & (14) \\
\hline 9 & $H C T^{*}$ & $.395(12), .105(8)$ & $6.5 \mathrm{E}-19(8)$ & $1.04(18)$ & $(9 \mathrm{~T})$ & (16) \\
\hline 10 & $\mathrm{LDH}$ & $.38(9), .11(14)$ & $8.9 \mathrm{E}-15(10)$ & $2.85(9)$ & (19) & (11) \\
\hline 11 & urea & $.373(8), .109(13)$ & $3.7 \mathrm{E}-14(11)$ & $3.19(8)$ & $(26)$ & (4) \\
\hline 12 & glucose & $.397(13), .112(17)$ & $8.7 \mathrm{E}-8(16)$ & $1.52(11)$ & (11) & $(9)$ \\
\hline 13 & BAS & $.42(17), .103(4)$ & $0.64(29)$ & $1.35(15)$ & $(15.5 \mathrm{~T})$ & $(13)$ \\
\hline 14 & $\mathrm{MCHC}$ & $.441(21), .118(26)$ & $8.1 \mathrm{E}-9(14)$ & $1.4(13)$ & $(9 \mathrm{~T})$ & $(21)$ \\
\hline 15 & LYM & $.41(15), .107(11)$ & $1.4 \mathrm{E}-4(20)$ & $0.81(19)$ & $(21)$ & $(12)$ \\
\hline 16 & $R D W . C V^{*}$ & $.422(18), .114(20)$ & $6.7 \mathrm{E}-10(12)$ & $1.42(14)$ & $(27)$ & (18) \\
\hline 17 & gender & $.541(30), .107(10)$ & $0.002(23)$ & $0.78(20)$ & $(9 \mathrm{~T})$ & $(25)$ \\
\hline 18 & creatine $*$ & $.387(10), .115(23)$ & $4.3 \mathrm{E}-9(13)$ & $0.43(21)$ & $(24)$ & $(10)$ \\
\hline 19 & sodium & $.415(16), .117(25)$ & $1.5 \mathrm{E}-5(18)$ & $0.32(23)$ & $(12.5 \mathrm{~T})$ & $(15)$ \\
\hline 20 & potassium & $.409(14), .115(22)$ & 7.7E-5 (19) & $0.29(25)$ & $(17.5 \mathrm{~T})$ & $(17)$ \\
\hline 21 & $M C V$ & $.454(26), .118(27)$ & $3.7 \mathrm{E}-6(17)$ & $1.05(17)$ & $(15.5 \mathrm{~T})$ & $(29)$ \\
\hline 22 & PLT & $.452(25), .112(16)$ & $0.217(27)$ & $1.1(16)$ & $(20)$ & $(27)$ \\
\hline 23 & $\mathrm{MPV}$ & $.467(27), .119(28)$ & $8 \mathrm{E}-8(15)$ & $0.37(22)$ & $(14)$ & $(24)$ \\
\hline 24 & EOS & $.48(28), .115(24)$ & $0.777(30)$ & $1.48(12)$ & $(12.5 \mathrm{~T})$ & (19) \\
\hline 25 & PDW & $.44(20), .114(19)$ & $4.7 \mathrm{E}-4(21)$ & $0.13(28)$ & $(22.5 \mathrm{~T})$ & $(26)$ \\
\hline 26 & $M O N$ & $.447(24), .111(15)$ & $0.09(26)$ & $0.24(26)$ & $(22.5 \mathrm{~T})$ & $(28)$ \\
\hline 27 & $A L T$ & $.445(23), .112(18)$ & $0.002(24)$ & $0.21(27)$ & $(25)$ & $(23)$ \\
\hline 28 & $\mathrm{AST}^{*}$ & $.425(19), .114(21)$ & $0.0014(22)$ & $0.12(30)$ & $(30)$ & $(20)$ \\
\hline 29 & chloride & $.444(22), .12(29)$ & $0.03(25)$ & $0.1(29)$ & $(29)$ & $(22)$ \\
\hline 30 & $M C H^{*}$ & $.509(29), .122(30)$ & $0.22(28)$ & $0.31(24)$ & $(28)$ & $(30)$ \\
\hline
\end{tabular}

Table 2: Similar to Table 1 for time-to-release analyses. 
medRxiv preprint doi: https://doi.org/10.1101/2022.01.05.22268765; this version posted January 6, 2022. The copyright holder for this preprint (which was not certified by peer review) is the author/funder, who has granted medRxiv a license to display the preprint in perpetuity.

It is made available under a CC-BY 4.0 International license .

\begin{tabular}{c|c|c|c}
\hline factor1 & factor 2 & $\begin{array}{c}\text { deceased samples: } \mathrm{n}, R^{2}(\text { linear}) /(\log ), \\
\mathrm{cc}(\text { Spearman) }, \mathrm{pv}(\text { Spearman })\end{array}$ & $\begin{array}{c}\text { survived samples: n, } R^{2}(\text { linear }) /(\log ), \\
\mathrm{cc}(\text { Spearman }), \mathrm{pv}(\text { Spearman })\end{array}$ \\
\hline urea & creatine & $94,0.58 / 0.61,0.78,9.7 \mathrm{E}-21$ & $308,0.42 / 0.61,0.57,1.6 \mathrm{E}-27$ \\
NEU & WBC & $89,0.99 / 0.98,0.99,6.8 \mathrm{E}-78$ & $257,0.87 / 0.98,0.91,1.4 \mathrm{E}-97$ \\
AST & ALT & $94,0.62 / 0.73,0.79,6.5 \mathrm{E}-21$ & $307,0.6 / 0.73,0.71,4.6 \mathrm{E}-48$ \\
RDW.CV & RDW.SD & $94,0.61 / 0.62,0.77,2.3 \mathrm{E}-19$ & $290,0.66 / 0.62,0.71,9.3 \mathrm{E}-46$ \\
HGB & HCT & $94,0.96 / 0.96,0.98,4.9 \mathrm{E}-64$ & $290,0.96 / 0.96,0.98,1.1 \mathrm{E}-210$ \\
MCV & MCH & $94,0.81 / 0.82,0.81,2.1 \mathrm{E}-23$ & $290,0.86 / 0.82,0.92,1.5 \mathrm{E}-122$ \\
\hline
\end{tabular}

Table 3: Factor pairs that have very strong correlation (with $R^{2}>0.6$ in both survived and deceased group, either in the original level or log-transformed level). The correlation coefficient (cc) and p-value for testing $\mathrm{cc}=0$ both refer to Spearman correlation. 
medRxiv preprint doi: https://doi.org/10.1101/2022.01.05.22268765; this version posted January 6, 2022. The copyright holder for this preprint (which was not certified by peer review) is the author/funder, who has granted medRxiv a license to display the preprint in perpetuity.

It is made available under a CC-BY 4.0 International license .

\begin{tabular}{|c|c|c|c|c|c|c|c|}
\hline rank & factor & VIM/T2D & $\operatorname{rank} 5 / \mathrm{T} 2 \mathrm{D}$ & VIM/T2R & $\operatorname{rank} 5 / \mathrm{T} 2 \mathrm{R}$ & Cox/T2D & Cox/T2R \\
\hline 1 & calcium & + & + & + & + & + & + \\
\hline 2 & WBC & + & + & + & + & + & + \\
\hline 3 & $\mathrm{NEU}(\rightarrow \mathrm{WBC})$ & + & + & + & + & + & + \\
\hline 4 & urea & + & + & + & & + & + \\
\hline 5 & d-dimer & & + & + & + & + & + \\
\hline 6 & RDW.SD & & + & + & + & + & + \\
\hline 7 & age & & & + & + & + & + \\
\hline 8 & ferritin & & & + & + & + & + \\
\hline 9 & glucose & + & + & + & & + & + \\
\hline 10 & creatine ( $\rightarrow$ urea) & + & + & & & + & + \\
\hline 11 & LDH & + & + & + & & & + \\
\hline 12 & LYM & + & + & & & + & + \\
\hline 13 & BAS & & + & & & + & \\
\hline 14 & HGB & + & & + & + & & + \\
\hline 15 & sodium & + & + & & & + & + \\
\hline 16 & $\mathrm{HCT}(\rightarrow \mathrm{HGB})$ & + & & & & & + \\
\hline 17 & potassium & & & & & + & + \\
\hline 18 & RDW.CV $(\rightarrow$ RDW.SD) & & & + & & + & + \\
\hline 19 & EOS & & & + & & + & \\
\hline 20 & AST & + & + & & & & \\
\hline 21 & $\mathrm{MCHC}$ & & & + & & & + \\
\hline 22 & chloride & + & + & & & + & \\
\hline 23 & $\operatorname{ALT}(\rightarrow \mathrm{AST})$ & & & & & & \\
\hline 24 & MPV & & & & & + & + \\
\hline 25 & gender & & & & & & \\
\hline 26 & PDW & & & & & & + \\
\hline 27 & PLT & & & & & & \\
\hline 28 & $\mathrm{MON}$ & + & & & & & + \\
\hline 29 & $\mathrm{MCV}$ & & & & & & \\
\hline 30 & $\mathrm{MCH}(\rightarrow \mathrm{MCV})$ & & & & & & \\
\hline
\end{tabular}

Table 4: The risk factor selection worksheet. T2D/T2R: time-to-death/time-to-release data. VIM/rank5: rank order from variable importance of the full RSF model (column 5 of Tables 1 and 2)/composite rank order (column 1 of Tables 1 and 2). If a factor is selected by either being among the top ranking variables by the corresponding error curve, or by the p-value $<0.001$ in $_{31}$ Cox regression, it is marked by + . 